\title{
NOTE
}

\section{Subcutaneous, abdominal, and thoracic encapsulated fat necrosis in bowhead whales Balaena mysticetus from Alaska, USA}

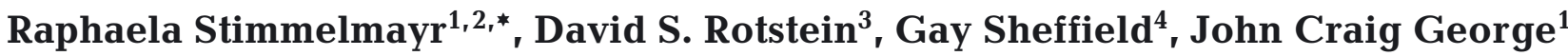 \\ ${ }^{1}$ Department of Wildlife Management, North Slope Borough, PO Box 69, Utqiagvik, Alaska 99723, USA \\ ${ }^{2}$ Institute of Arctic Biology, University of Alaska Fairbanks, PO Box 757000, Fairbanks, Alaska 99775-70, USA \\ ${ }^{3}$ Marine Mammal Pathology Services, Olney, Maryland 20832, USA \\ ${ }^{4}$ Alaska Sea Grant, University of Alaska Fairbanks-Marine Advisory Program, Nome, Alaska 99762, USA
}

\begin{abstract}
We describe a case series of encapsulated fat necrosis with subcutaneous, abdominal, and thoracic locations in 7 subsistence-harvested bowhead whales Balaena mysticetus. Masses had a variably-dense fibrous capsule surrounding necrotic adipocytes and calcium salts (saponification). One animal also had prior concussive injury, pleural fibrosis, and hepatic lipoma; the other animals had no significant findings. The described condition is uncommon in bowhead whales, with 7/575 (1.2\%) observed from 1996 to 2015. The exact mechanisms of development of encapsulated fat necrosis in bowhead whales remain to be determined. Encapsulated fat necrosis has been reported in other baleen whales, humans, and cows. It is usually an incidental finding during post-mortem examination that needs to be differentiated from neoplastic and inflammatory lesions, as the latter may have public health implications. Assessment of further cases in bowhead whales and other baleen whales is warranted to better understand their pathogenesis.
\end{abstract}

KEY WORDS: Aboriginal whaling $\cdot$ Alaska $\cdot$ Balaena mysticetus $\cdot$ Bowhead whale $\cdot$ Encapsulated fat necrosis $\cdot$ Subcutaneous $\cdot$ Abdominal $\cdot$ Thoracic $\cdot$ Husks

\section{INTRODUCTION}

Despite their extreme longevity, few disease conditions have been observed during post-mortem examination of subsistence-harvested Bering-ChukchiBeaufort Seas (BCB) bowhead whales Balaena mysticetus (Stimmelmayr et al. 2021). Here, we report the incidence, sex and age distribution, and gross and histopathological characteristics of encapsulated fat necrosis that presented as subcutaneous (interface between muscle tissue and blubber), abdominal, and thoracic masses in 7 bowhead whales harvested for subsistence by Alaskan Inupiaq between 1996

${ }^{*}$ Corresponding author:

raphaela.stimmelmayr@north-slope.org and 2015 near the coastal communities of Utqiagivik $\left(71.29^{\circ} \mathrm{N}, 156.79^{\circ} \mathrm{W}\right)$, Kaktovik $\left(70.13^{\circ} \mathrm{N}, 143.62^{\circ} \mathrm{W}\right)$, and Wainwright $\left(70.63^{\circ} \mathrm{N}, 160.03^{\circ} \mathrm{W}\right)$, Alaska, USA. Encapsulated fat necrosis, with subcutaneous and abdominal locations, is a well-known adipose lesion described in humans and cows (Burgdorf \& Hurt 2011). It is usually an incidental finding that needs to be distinguished from neoplastic or inflammatory lesions. Given the nutritional importance of $\mathrm{BCB}$ bowhead whales for the 11 Alaskan whaling communities, continued health monitoring of landed bowhead whales is essential from a food safety and food security point of view.

() The authors 2021. Open Access under Creative Commons by Attribution Licence. Use, distribution and reproduction are unrestricted. Authors and original publication must be credited. 
Table 1. Dimensions, weight, color, and histopathological findings of subcutaneous, abdominal, and thoracic encapsulated fat necrosis in 7 bowhead whales Balaena mysticetus. Bowhead whale 15KK1 was landed near Kaktovik $\left(70.13^{\circ} \mathrm{N}\right.$, $\left.143.62^{\circ} \mathrm{W}\right), 96 \mathrm{WWX}$ was landed near Wainwright $\left(70.63^{\circ} \mathrm{N}, 160.03^{\circ} \mathrm{W}\right)$, and all other specimens were from whales landed near Utqiagvik $\left(71.29^{\circ} \mathrm{N}, 156.79^{\circ} \mathrm{W}\right)$ Alaska, USA, between 1996 and 2015. M: male; F: female; Unk: unknown; TBL: total body length; N: number of masses observed; FC: fibrous capsule; OM: osseous metaplasia; FN: fat necrosis; FNS: fat necrosis and saponification; PST: pyogranulomatous steatitis; LST: lymphoplasmacytic steatitis; DM: dystrophic mineralization; CL: ceroid-lipofuscin deposition

\begin{tabular}{|c|c|c|c|c|c|c|c|c|}
\hline ID & Sex & $\begin{array}{l}\text { TBL } \\
(\mathrm{m})\end{array}$ & $\mathrm{N}$ & Size $(\mathrm{mm})$ & $\begin{array}{l}\text { Weight } \\
\text { (g) }\end{array}$ & Color & $\begin{array}{l}\text { Histopathologic } \\
\text { findings }\end{array}$ & Location \\
\hline 96 WWX & Unk & Unk & 1 & $110 \times 85 \times 40$ & 270 & Beige & FNS, FC & Subcutaneous chest \\
\hline $11 \mathrm{~B} 7^{\mathrm{a}}$ & M & 15.4 & 2 & $70 \times 60 \times 35$ & $103 ; 59$ & Grey & $\mathrm{FC}, \mathrm{OM}, \mathrm{FN}$ & Subcutaneous chest \\
\hline $13 \mathrm{~B} 20$ & $\mathrm{~F}$ & 8.6 & 1 & $70 \times 60 \times 45$ & 108 & Beige & FC, FNS & Abdominal attached \\
\hline 14B15 & $\mathrm{F}$ & 10.2 & 1 & $110 \times 110 \times 50$ & 285 & Beige & FC, FNS, CL & Subcutaneous chest \\
\hline 15B16 & M & 10.9 & 1 & $110 \times 55 \times 30$ & 107 & Pink & FC, FN, PST & Abdominal loose \\
\hline 15B20 & $\mathrm{F}$ & 11.9 & 1 & $90 \times 85 \times 52$ & 273 & Pink & FC, FNS, DM, CL & Abdominal loose $\mathrm{b}^{\mathrm{b}}$ \\
\hline $15 \mathrm{KK} 1^{\mathrm{c}}$ & M & 12.8 & $50-100$ & 40-150 & $25-1490$ & Pink & FC, DM, FN, OM, LST & $\begin{array}{l}\text { Thoracic attached } \\
\text { and loose }\end{array}$ \\
\hline \multicolumn{9}{|c|}{$\begin{array}{l}{ }^{a} \text { Only one of the } 2 \text { masses was intact and measured. The second mass had a } 10 \times 25 \mathrm{~mm} \text { solid osseous body at the core con- } \\
\text { firmed by radiographs and had been sectioned } \\
\text { bMass was discovered after the animal had been flensed and hunters reported it washed out from the abdominal cavity } \\
\text { cNumber of masses estimated; a subset }(\mathrm{n}=11) \text { of thoracic masses was collected, measured, and weighed. The range of } \\
\text { diameters observed is provided }\end{array}$} \\
\hline
\end{tabular}

\section{MATERIALS AND METHODS}

Seven whales landed between 1996 and 2015 were sexed and aged based on a combination of published criteria including genital groove length and total body length (George et al. 1999). Whales were examined within 5-10 h of death. Post-mortem examination aligned with community-specific customary bowhead whale butchering processes for food consumption (Stimmelmayr et al. 2017). Organs collected for histopathology varied, but typically included the encapsulated masses, lung, lymphoid tissue (spleen and/or lymph node), gonads, liver, kidney, heart, and skin. Masses only were collected from 3 whales.

Tissue samples were fixed in $10 \%$ buffered formalin, processed routinely, sectioned at 5-7 $\mu \mathrm{m}$, and stained with hematoxylin and eosin. Subcutaneous, abdominal, and thoracic masses were stained with additional stains including periodic acid-Schiff (PAS), Prussian blue, Fontana-Masson, von Kossa, and Hall's bilirubin to identify deposited pigment. Masson's trichrome stain was used to highlight the capsule of the masses. For 1 whale $(15 \mathrm{KK} 1)$ with thoracic masses initially suspected to be thoracic granulomas, additional stains including Gram, Grocott methenamine silver (GMS), Fite's acid-fast, and ZiehlNeelsen stains were applied to screen for fungi and bacteria.

\section{RESULTS}

The total length of the 7 bowhead whales with encapsulated adipose lesions ranged from 8.6 to $15.4 \mathrm{~m}$ (mean $\pm \mathrm{SD}=11.6 \pm 2.4 \mathrm{~m}$ ) (Table 1). Sex and age class distribution was 3 immature females, 2 immature males, 1 mature male, and 1 unknown (96 WWX) (Table 1). Grossly, the masses were ellipsoid to round (Table 1). Masses were beige-pink to grey, firm, and with a smooth or roughened surface (Fig. 1). Single masses were present in 5 of the bowhead whales, and 2 animals had 2 to approximately 100 masses, respectively. In 2 bowhead whales, 3 subcutaneous masses were recovered during blubber flensing and were not attached to the muscle fascia or blubber subcutaneous fat tissue (Fig. 1A,B). In 3 individuals, single abdominal masses were recovered (Fig. 1C), with 2 unattached and 1 lightly attached to the mesentery; the latter was without obvious vascular connections. Multiple pendulant and loose thoracic round masses were recovered from 1 whale (15KK1). The masses were dorsally attached on the right side of the thoracic vertebra to the costal parietal pleura (Fig. 1D). There was no gross evidence for compression of the lungs due to these masses. On cut surface, subcutaneous masses had multiple irregular concentric layers with discolored fatty tissue and calcifications (Fig. 1B). In 2 of the 3 abdominal masses, adipose tissue was yellow with surrounding layers of fibrous 

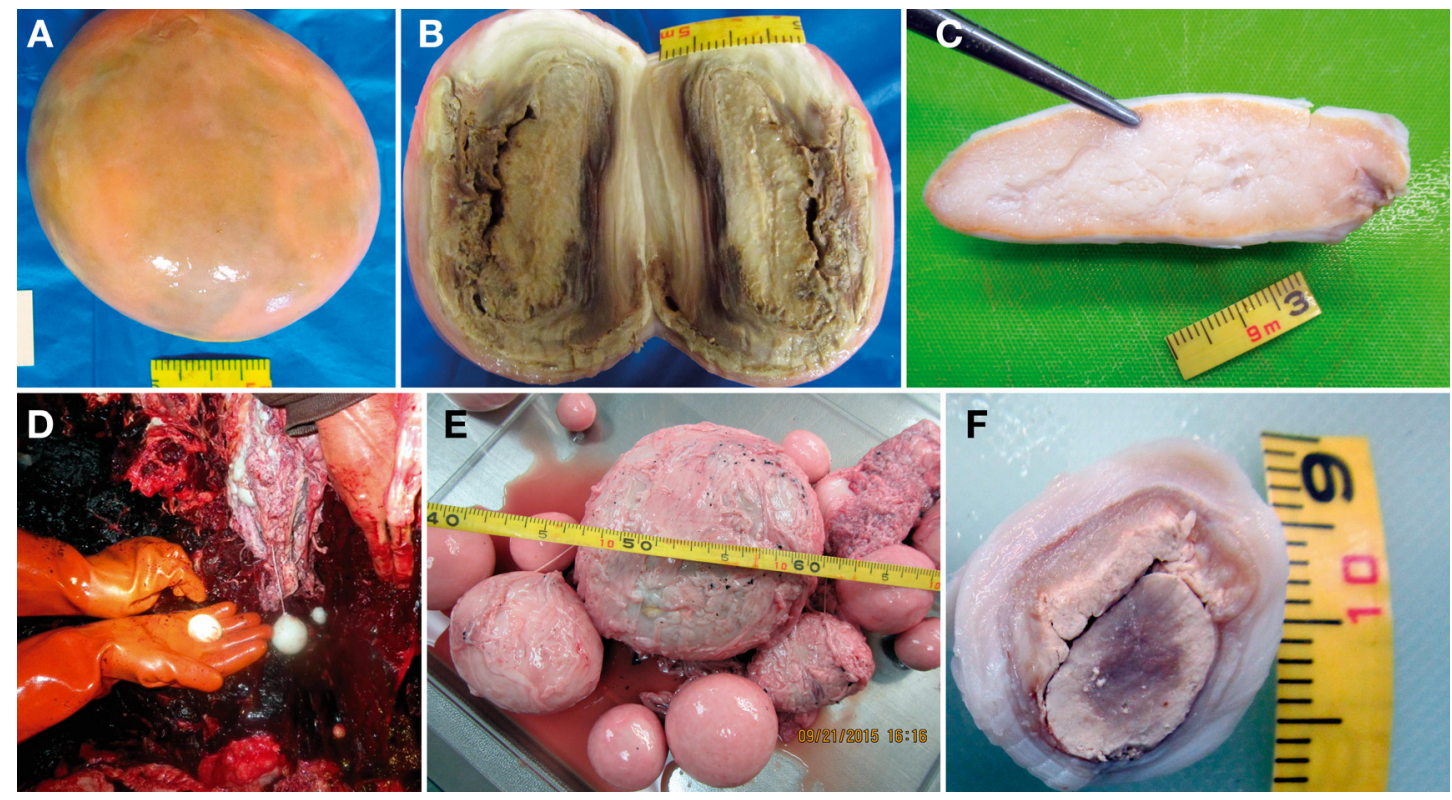

Fig. 1. Variable gross presentations of encapsulated fat necrosis in bowhead whales Balaena mysticetus. (A) Subcutaneous oval mass $(110 \times 110 \times 50 \mathrm{~mm})$, yellow-white appearance with a firm smooth surface (whale ID: 14B15). (B) Cross section of the mass depicted in (A), showing multiple irregular concentric fibrous layers with discolored beige pasty material at the core. (C) Cross section of an abdominal elongated oval mass $(110 \times 55 \times 40 \mathrm{~mm})$, with yellow fatty tissue and surrounding concentric fibrous layers (15B16). (D) In situ pendulant thoracic masses (15KK1). (E) Variable gross presentation of thoracic masses depicted in (D), pink-white appearance with firm smooth or roughened surfaces. (F) Cross section of one of the masses depicted in (D), showing thick concentric fibrous layers and a white caseated dry core. Scale is in cm

connective tissue (Fig. 1C). Thoracic masses were characterized by thick fibrotic capsules, roughened and smooth surfaces, and a white caseated dry core (Fig. 1E,F). Two masses had a green caseated dry core.

No significant gross findings were noted in 6 of the whales. Additional gross findings in the whale with thoracic masses (15KK1), which was noted to exhibit abnormal ante-mortem swimming behavior, included pleural fibrosis hepatic lipoma (previously reported by Stimmelmayr et al. 2017), asymmetric testes (left: $97 \mathrm{~cm}$ vs. right: $89 \mathrm{~cm}$ ), and an old whale bombassociated tailstock injury (left lateral). The tailstock injury ( $213 \mathrm{~cm}$ anterior of flukes) consisted of a prominent penetration scar covered by whale lice $(\sim 200)$, and an underlying cylindrical cavity estimated to be $100 \mathrm{~cm}$ long and $20 \mathrm{~cm}$ wide. The height was not measured. The cavity contained 5 separate components of an unexploded 1950s-style whale bomb lance (Ebenezer Pierce type) (Sheffield 2016). Initials on the projectile were traced to a known whaling captain (deceased) who had reported having struck and lost a bowhead whale during the 1960s.

On histopathological examination, all masses were encapsulated by fibrous connective tissue of variable thickness, which was stained dark blue under Mas- son's trichrome staining (Fig. 2A,B). All masses were composed of numerous mature adipocytes, characterized by a large clear cytoplasm and a flattened or inconspicuous nucleus at the periphery. In 2 whales (14B15 and 15KK1), scattered throughout the masses were low to moderate numbers of collagen fibers. Multifocally, there were areas of fat necrosis, characterized by the loss of cell outlines and replaced by pooled accumulation of an amorphous, deep eosinophilic to amphophilic substance (Fig. 2C,D). Furthermore, basophilic, granular to amorphous, von Kossapositive calcium salts (saponification) were observed within the necrotic adipose tissue and in the surrounding fibrous stroma (Fig. 2E,F). Granular basophilic mineral deposition (dystrophic mineralization) was observed in 1 whale, and formation of bone (osseous metaplasia) was observed in 2 of the 7 whales. PAS-positive ceroid-lipofuscin pigments were present in 14B15 and 15B20.

Based on the special stains, hemosiderin, hematoidin, melanin, and bilirubin were not present. Inflammation was uncommon and included lymphoplasmacytic and pyogranulomatous infiltrates in 15KK1, and based on the special stains, no bacteria, including acid-fast bacteria, metazoans, or fungi were present. The site of the bomb in 15KK1 was infiltrated by 

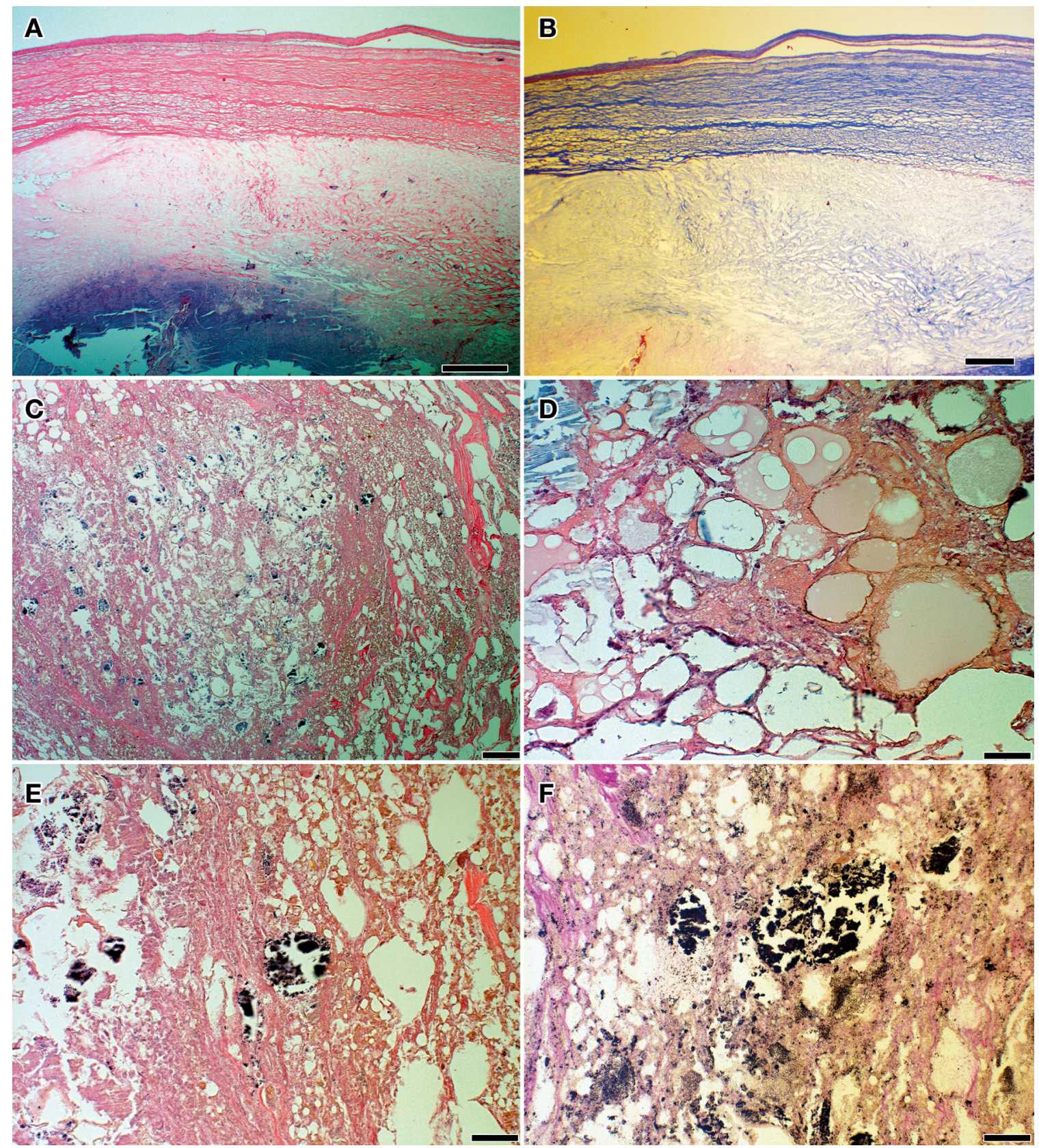

Fig. 2. Photomicrographs showing characteristic staining and physical properties of encapsulated fat necrosis in bowhead whales Balaena mysticetus. (A) Dense capsule surrounding necrotic fat. Deposition of calcium salts (saponification) is evident. $\mathrm{HE}_{;}$bar $=200 \mu \mathrm{m}$. (B) Capsule composed of layers of dark blue-staining collagen. Masson's trichrome; bar $=200 \mu \mathrm{m}$. (C) Necrosis and collapse of adipocytes. HE; bar $=500 \mu \mathrm{m}$. (D) Clusters of necrotic adipocytes. HE; bar $=200 \mu \mathrm{m}$. (E) Basophilic, granular mineral within the mass. $\mathrm{HE}$; bar $=200 \mu \mathrm{m}$. (F) Granular mineral stains. van Kossa; bar $=200 \mu \mathrm{m}$

neutrophils with surrounding fibroblasts (fibroplasia) and mature collagen. Other histopathologic findings from 15KK1 included pleural fibrosis, hepatic lipoma, mild hepatic hemosiderosis, and testicular atrophy. Focal and mild chronic interstitial nephritis was found in 15B20.

\section{DISCUSSION}

Masses of similar gross appearance and anatomical distribution (subcutaneous, abdominal, thoracic) but with limited histopathological description have been reported from post-mortem examination of landed 
baleen whales (blue whale Balaenoptera musculus, fin whale $B$. physalus, humpback whale Megaptera novaeangliae, Bryde's whale $B$. brydei/edeni, and sei whale $B$. borealis) during pelagic commercial whaling in the Antarctic (1948/49) and South Africa (1962/1963) (Cockrill 1951, 1960, Uys \& Best 1966).

In humans and cows, subcutaneous and abdominal encapsulated fat necrosis is described as firm, mobile, ivory-hued nodules with a distinct fibrotic capsule, absence of vascular connection, and yellow on cut surface (Anonymous 1926, Przyjemski \& Schuster 1977, Herzog et al. 2010, Burgdorf \& Hurt 2011). The adipose tissue inside can be normal or with areas of necrosis, inflammation, fibrosis, and calcification. Lesion growth over time is thought to occur by accumulation of lamellar units of fibrosis and acquisition of nutrients by diffusion. Dimensions of encapsulated fat necrosis in bowhead whales (Table 1) are comparable to what has been reported for sei whales (up to $60 \mathrm{~mm}$ ) and cows $(60-80 \mathrm{~mm})$, but are generally larger than those reported for humans (Uys \& Best 1966, Burgdorf \& Hurt 2011, Huang et al. 2011).

Depending on the anatomical location, differing etiologies have been proposed for encapsulated fat necrosis. Subcutaneous encapsulated fat necrosis case reports in humans have been associated with prior trauma (Hurt \& Santa Cruz 1989, Burgdorf \& Hurt 2011). In the absence of prior trauma history, origin of encapsulated fat necrosis is linked to rapid vascular insufficiency and or tissue ischemia associated with underlying collagen and endocrine-metabolic disturbances (Anonymous 1926, Herzog et al. 2010, Hanson et al. 2014, Ban 2016). Cockrill (1951, 1960) did not discuss the role of trauma in the etiology of subcutaneous encapsulated bodies in large whales, colloquially known as 'husks' among whaler men, and thought that the masses were of parasitic origin. However, he noted the preferred anatomical location being within and surrounding the psoas musculature, the latter being the commonest site for penetrating trauma from harpoons and Discovery marking schemes (Rayner 1940). Uys \& Best (1966) excluded a parasitic origin in their case material and proposed that unknown trauma history was a likely cause for these externally located encapsulated masses (associated with blubber or muscle tissue) resulting in localized ischemia and tissue necrosis. We cannot exclude a possible role for an unknown trauma history for subcutaneous encapsulated fat necrosis in bowhead whales, but gross evidence suggesting trauma history (i.e. external scarring and fibrous blubber texture) were absent in both bowhead whales with subcutaneous encapsulated fat necrosis. Although specula- tive, excessive lipid reserves, characteristic of bowhead whales (George et al. 2015), could predispose these whales to compromised adipose tissue perfusion and resulting tissue ischemia. Tissue ischemia has been observed in humans and experimental animal models of obesity (e.g. obese Zucker rat) (Anonymous 1926, Stapleton et al. 2008).

Abdominal encapsulated fat necrosis originates by infarction of epiploic appendices caused by torsion or thrombosis with subsequent inflammatory cellular response and capsule formation (Dockerty et al. 1956). Bowhead whales per se do not have epiploic appendices, but torsion or thrombosis of abundantly present internal fat deposits is a possibility. Although speculative, rolling behavior of bowhead whales (Würsig \& Clark 1993) could facilitate accidental torsion of internal fat depots. In dogs and cats, pancreatitis leading to leakage of pancreatic enzymes and subsequent abdominal fat saponification has been identified as a common process resulting in abdominal fat necrosis (Schwarz et al. 2000, Adamama-Moraitou et al. 2008). Pancreatic tissue was not collected from the 3 whales with abdominal masses, thus we cannot exclude the presence of pancreatitis; however, pancreatic lesions including pancreatitis appear to be uncommon $(\sim 3.5 \%)$ in bowhead whales (Stimmelmayr et al. 2021).

Uys \& Best (1966) speculated that decompression stresses and gaseous emboli resulting in localized ischemia and tissue necrosis were likely mechanisms for abdominal and thoracic encapsulated fat necrosis in sei and Bryde's whales. An infectious etiology was initially considered for 15KK1 which presented with numerous thoracic masses. There was no histopathological evidence of infectious agents; however, this may reflect the chronicity (post-infection). The multidecadal embedment ( $\sim 49 \mathrm{yr})$ of the projectile is remarkable; however, although rare, historic whale harvest projectiles and/or research instrumentation anchored subcutaneously into whales have been previously documented in Western Arctic bowhead whales (George \& Bockstoce 2008).

Independent of etiology, subcutaneous and abdominal encapsulated fat necrosis described here is uncommon in bowhead whales $(1.2 \% ; 7 / 575)$. For examined sei and Bryde's whales, Uys \& Best (1966) reported a lower prevalence of $0.6 \%$ (13/2000) for muscle and fat necrosis bodies, respectively. No quantitative assessment of prevalence is available for subcutaneous and abdominal masses from examination of landed Antarctic whales, but Cockrill (1960) noted them as being commonly observed. The detection rate of these encapsulated masses in bowhead whales, based on size, coloration, and marble-like ap- 
pearance, likely varies by anatomical location. Subcutaneous encapsulated bodies are unlikely to be overlooked by aboriginal whaling crews during the flensing process. Loose abdominal and thoracic masses are more likely to be missed during post-mortem examination given the size of viscera and challenging field logistics (Stimmelmayr et al. 2017). As was the case for $15 \mathrm{KK} 1$, detection of pendulant thoracic masses is highly likely. The biological behavior of these lesions is unknown, but evidence for co-morbidity with the exception of 15KK1 (i.e. hepatic lipoma, pleural fibrosis) was absent. Total body length of whales from this study (8.6-15.4 $\mathrm{m}$ ) falls within the reported range for landed bowhead whales (Suydam \& George 2018).

In conclusion, our small case series presents gross and comprehensive histopathological staining characterization of encapsulated fat necrosis in bowhead whales. Although an incidental finding, encapsulated fat necrosis needs to be distinguished from neoplastic and inflammatory lesions, as the latter may have public health implications. Assessment of additional case material including those from other baleen whale species will be helpful to better understand the etiology of encapsulated fat necrosis in large baleen whales.

Acknowledgements. We are particularly grateful to Freddie Aishanna for graciously allowing us to examine the whale lance fragment (15KK1). Consultations with Alaska Eskimo Whaling commission (AEWC) leadership and Kaktovik Whaling Captains Association members were essential in assessing the food safety and public health concerns associated with 15KK1. This study would have not been possible without the long-term support by the Whaling Captains Associations of Barrow (Utqiagivik), Wainwright, and Kaktovik, Alaska, of the bowhead harvest monitoring program and their continued interest in bowhead whale health research. This study was funded by qualified outer continental shelf oil and gas revenues by a substantial grant (F12AF01265) from the Coastal Impact Assistance Program, US Fish and Wildlife Service, the US Department of the Interior, and the North Slope Borough Department of Wildlife Management. Collection of marine mammal tissues (2011-2015) was conducted under NMFS permits 17350-01 and -02.

\section{LITERATURE CITED}

Adamama-Moraitou KK, Prassinos NN, Galatos AD, Tontis DK, Rallis TS (2008) Isolated abdominal fat tissue inflammation and necrosis in a cat. J Feline Med Surg 10: 192-197

Anonymous (1926) Localized saponification of fat. Edinburgh Med J 33:627-631

Ban M (2016) Nodular-cystic fat necrosis - a review of 147 Japanese patients. J Dermatol Res 1:65-68

Burgdorf WH, Hurt MA (2011) Mobile encapsulated adipose tissue (MEAT) of cows and humans: a distinct nonneoplastic entity. Int J Surg Pathol 19:576-582

Cockrill WR (1951) Antarctic whaling, the role of the veterinary surgeon in the whaling industry, with special refer- ence to standards of inspection in the production of whale meat for human consumption and some notes of the pathology of the baleen whales. Vet Rec 63:111-125

* Cockrill WR (1960) Pathology of Cetacea. A veterinary study on whales. Part I and II. Br Vet J 116:133-189

* Dockerty MB, Lynn TE, Waugh JM (1956) A clinicopathologic study of the epiploic appendages. Surg Gynecol Obstet 103:423-433

* George JC, Bockstoce JR (2008) Two historical weapon fragments as an aid to estimating the longevity and movements of bowhead whales. Polar Biol 31:751-754

George JC, Bada J, Zeh J, Scott L, Brown SE, O'Hara T, Suydam R (1999) Age and growth estimates of bowhead whales (Balaena mysticetus) via aspartic acid racemization. Can J Zool 77:571-580

* George JC, Druckenmiller ML, Laidre KL, Suydam RS, Person BT (2015) Bowhead whale body condition and links to summer sea ice and upwelling in the Beaufort Sea. Prog Oceanogr 136:250-262

* Hanson P, Pandit M, Menon V, Roberts S, Barber TM (2014) Painful fat necrosis resulting from insulin injections. Endocrinol Diabetes Metab Case Rep 2014:140073

*Herzog K, Burgdorf W, Hewicker-Trautwein M (2010) Mobile encapsulated bodies comprising fat necrosis and fibrous tissue in the abdominal cavity of cows. J Comp Pathol 143:309-312

*Huang CH, Lin SC, Chang KC, Chow NH (2011) Numerous peritoneal loose bodies with ileus. Histopathology 58: 318-319

*Hurt MA, Santa Cruz DJ (1989) Nodular-cystic fat necrosis. A reevaluation of the so-called mobile encapsulated lipoma. J Am Acad Dermatol 21:493-498

Przyjemski CJ, Schuster SR (1977) Nodular-cystic fat necrosis. J Pediatr 91:605-607

Rayner GW (1940) Whale marking. Progress and results to December 1939. Discov Rep 19:245-284

* Schwarz T, Morandi F, Gnudi G, Wisner E, Paterson C, Sullivan $M$, Johnston P (2000) Nodular fat necrosis in the feline and canine abdomen. Vet Radiol Ultrasound 41:335-339

Sheffield G (2016) Kaktovik - 2015 Season. UAF Alaska Sea Grant (Nome) Report to the Kaktovik Whaling Captains Association, Kaktovik, AK

Stapleton PA, James ME, Goodwill AG, Frisbee JC (2008) Obesity and vascular dysfunction. Pathophysiology 15: 79-89

Stimmelmayr R, Rotstein D, Seguel M, Gottdenker N (2017) Hepatic lipomas and myelolipomas in subsistenceharvested bowhead whales Balaena mysticetus, Alaska (USA): a case review 1980-2016. Dis Aquat Org 127: $71-74$

Stimmelmayr R, Rotstein D, Sheffield G, Brower HK, George JC (2021) Diseases and parasites. In: George JC, Thewissen JGM (eds) The bowhead whale. Balaena mysticetus: biology and human interactions. Academic Press, p 471-498

Suydam RS, George JC (2018) Subsistence harvest of bowhead whales (Balaena mysticetus) by Alaskan Eskimos, 1974 to 2016. Paper SC/67b/AWMP6 presented to the Scientific Committee of the International Whaling Commission

Uys CJ, Best PB (1966) Pathology of lesions observed in whales flensed at Saldanha Bay, South Africa. J Comp Pathol 76:407-412

Würsig B, Clark CW (1993) Behavior. In: Burns JJ, Montague JJ, Cowles CJ (eds) Special Publication 2: the bowhead whale. The Society of Marine Mammalogy, Moss Landing, CA, p 157-199 